\title{
Wireless UGV for Target Tracking and Obstacle Detection using Live Surveillance
}

\author{
Mohanraj, Meenaa Kumari.M, Ramya.S.
}

\begin{abstract}
: our aim is to develop a project that will benefit society. But nowadays it is employed to assist human in surveillance, rescue and recovery missions. This paper presents the prototype model of an $U G V$ which is operated wirelessly through manual navigation commands based on the live video captured from the IP camera mounted on the board. The distance measurement is done by the Ultrasonic sensor from the obstacle and displayed in the LCD. The target tracking as well as attacking is done based on the obstacle and environment situation monitored in the live video. This complete set up and working of the UGV is described further in this paper.

Keywords : component ; Unmanned Ground Vehicle $(U G V)$; ZigBee ; LCD 16×2 ; Sensor.
\end{abstract}

\section{INTRODUCTION}

It is a ground based mobile robots that can sense and interact with its environment

A.Block diagram and its description of ugv

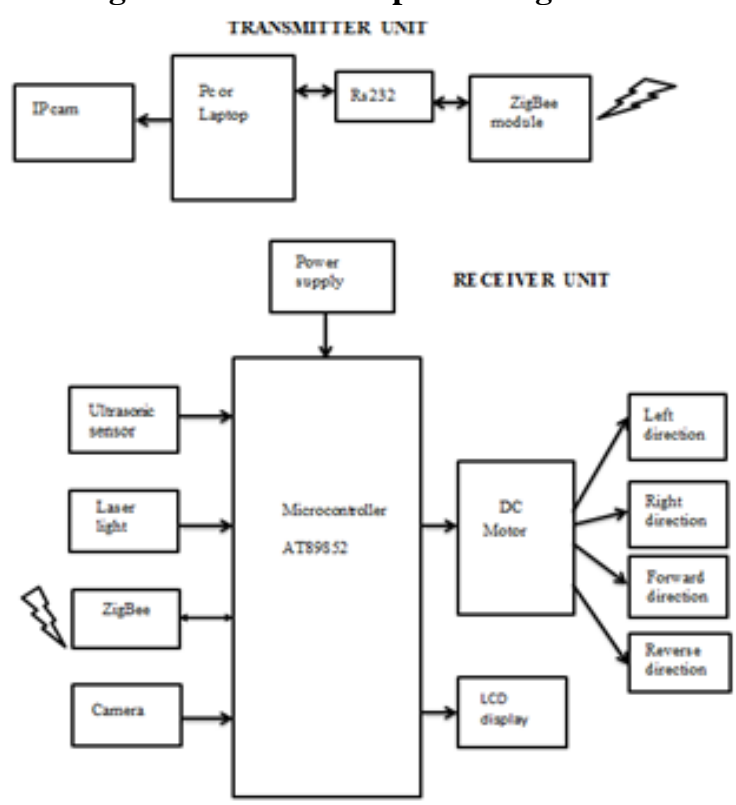

Fig 1. Block diagram of UGV

In this, it can be used to ensure the security of various areas such as military facilities. The UGV should be able to move outdoors, in normal roads with small bumps, offering sufficient range. UGV can relieve humans from hard,

Revised Manuscript Received on August 22, 2019.

Mohanraj Assistant Professor, Department of Electronics And Communication Engineering,, Bharath Institute of Higher Education and Research, Chennai, India.dspmohanraj@gmail.com

Meenaa Kumari.M, Assistant Professor, Department of Electronics And Communication Engineering,, Bharath Institute of Higher Education and Research, Chennai, India.meenumathi.m@gmail.com

Ramya.S., Assistant Professor, Department of Electronics And Communication Engineering,, Bharath Institute of Higher Education and Research, Chennai, India .ramyasamdra@gmail.com difficult, dangerous tasks. These command system classified by the level of supervision into full autonomous to fully teleoperated.[16-20] Fully tele operated control is considered a major technology. The real time obstacle detection and target tracking is the major fields of the project in the area of teleoperated vehicles. Our project deals with the sensing and identification of unauthorized personnel or any obstacles in a highly preserved environment. It can continuously monitor the areas which is the biggest advantage in this project compared with other systems. UGV can able to distinguish target from obstacles and navigate through obstacles to get target.[1-5]

\section{II.BLOCK DIAGRAM DESCRIPTION}

Power Supply:

This gives $12 \mathrm{~V}$ supply to all circuit boards

Ultrasonic Sensor: The sensor used in this vehicle is used to detect the obstacle within the environment and also measure the distance between the vehicle and obstacle which is displayed in the LCD display.

Laser Light: With the help of command, laser pulse is send in a narrow beam towards the enemy to target and also determine the distance between the obstacle and vehicle.

IP Camera: This camera monitors the environment through which UGV travels and provides the live video to the user. DC Motor Unit: It consists of two $12 \mathrm{~V} \mathrm{DC}$ motors to drive the wheels. Direction of these motors is controlled by the user's commands such as forward, backward, left and right with the help of visual studio.

LCD Display: The commands are displayed in the LCD given by the user in the base station and also display the distance and speed.[6-11]

AT89S52 microcontroller: This receives the outputs of ultrasonic sensor

ADC: The analog signal from the ultrasonic sensor when the obstacle detected sends to the ADC. The microcontroller receives only digital signal

\section{III .HARDWARE REQUIREMENTS}

- Power supply

- AT89S52 microcontroller

- ZigBee Unit

- Ultrasonic Ranging module HC-SR04

- IP Camera

- ULN2803 Motor Driver

- DC motor

- Laser Indicator

- LCD 16×2 Display

- MAX232 


\section{Wireless Ugv For Target Tracking And Obstacle Detection Using Live Surveillance}

\section{SOFTWARE REQUIREMENT}

Algorithm

1. Start UGV movement.

2. Power supply initializes all the board.

3. On-board live video capture.

4. Check for deviation.

5. If yes go to 7 , if no move in desired direction.

6. All direction displayed in LCD.

7. Check for Obstacle detection.

8. If yes go to 8, if no UGV stops.

9. Measure the distance from obstacle.

10. Distance display in LCD.

11. If no monitored in the same path.

12. Check for Target detection from video.

13. If yes attack command to UGV.

14. If no monitored in same lane.

15. Switch off UGV.

16. Video processed in MATLAB.

17. Converted into frames.

18. Stored as file.

\section{FLOWCHART}

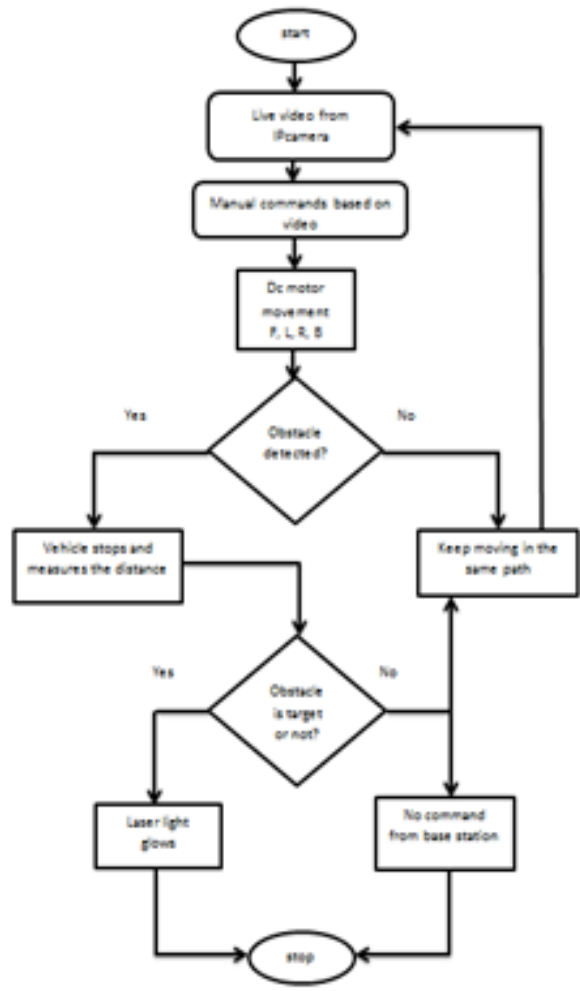

Fig. 2. Overall methodology

Overall implementation

Following methods are implemented:-

- Obstacle avoidance.

- System on and off control based on obstacle.

- Target analyzing based on live video.

- Video transmission.

- Movement of vehicle in our different directions.

- Video to images in frames in MATLAB.

Software requirements

- MATLAB 7.7

- Keil $\mu$ Vision IDE

- ANDROID platform

\section{V.DESIGN OF PROPOSED MODEL}

In this project we implemented a UGV that can drive by manual navigation command given from base station. Here, laptop or pc can be selected as a base station. In this hardware IP camera such as android supported mobile can be placed and using its IP address the live video can be made to display in base station. Further these images can be processed in MATLAB for data storage for future purpose. UGV continuously monitor the environment and detects the obstacle using ultrasonic sensor. The sensor measures the distance from the obstacle and displayed in the LCD $16 \times 2$. Simultaneously from the video captured obstacle detected is checked for a intruder identification. Once it is identified the object is targeted and laser indicator is set on from the base station. The programming of microcontroller is done in $\mathrm{C}$ language and coding for above operation is done and checked error free in Keil $\mu$ Vision IDE[12-15]

\section{RESULT}

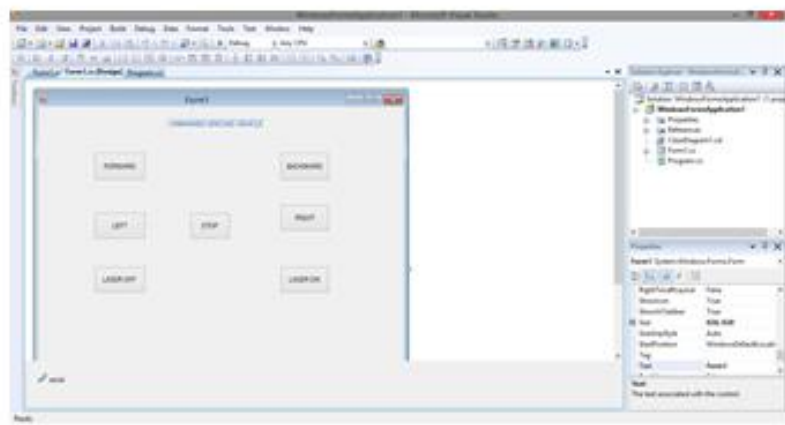

Fig. 3. UGV movement

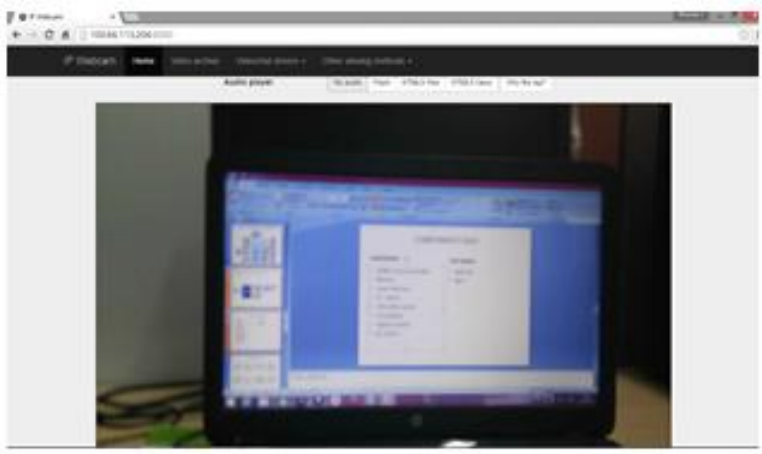

VII ADVANTAGES AND APPLICATIONS

Advantages:-

- Autonomous Navigation

- Recording of environmental parameters such as temperature

Applications:-

- UGVs are being developed for peace keeping operations,

- Used for Ground surveillance operations,

\section{CONCLUSION:}

The project was aimed at developing wireless UGV for target tracking and with multi directional abilities and for live stream purposes. Successful real time code is generated by using Kiel $\mu$ Vision IDE in C language. Obstacles distance is by Ultrasonic ranging Module and displayed in LCD. PC is 
used for the successful of our results data like (video snaps) with the help of wireless communication by using ZigBee unit. UGV is manipulated with the special usage of wirelessly transmitting navigation commands from the base station based on the video conferred from the on-board camera.

\section{FUTURE WORKS}

Future work can comprise of automatic mode of working after disincentive detection and path outlining by the GPS module. The captured obstacle outlining data can be implemented in different software platforms.

\section{X.ACKNOWLEDGEMENT}

We legitimately pleased and thankful to Mrs. N. Selvarani Assistant Professor for her valuable, constructive and effective ideas to undergo this project

\section{REFERENCES}

1. Kongkham, D. \& Sundararajan, M. 2019, "Distributed wideband sensing method for faded dynamic spectrum access", International Journal of Innovative Technology and Exploring Engineering, vol. 8, no. 10, pp. 4309-4312.

2. Balaji, S., John Paul Praveen, A. \& Mohanraj, R. 2019, "Recognizable proof and analysis of palm print in biometric authentication system using bayes techniques", International Journal of Innovative Technology and Exploring Engineering, vol. 8, no. 9 Special Issue 3, pp. 1126-1129.

3. Kavitha, G., Priya, N., Velvizhi, R. \& Allin Geo, A.V. 2019, "Parallel computation in correspondence and signal processing", International Journal of Innovative Technology and Exploring Engineering, vol. 8, no. 9 Special Issue 3, pp. 1136-1139.

4. Hema, R., Sundararajan, M. \& Balaji, S. 2019, "Smartphone control robot with automatic firing gun", International Journal of Innovative Technology and Exploring Engineering, vol. 8, no. 9 Special Issue 3, pp. 625-627.

5. Kaliyamurthie, K.P., Sundar Raj, B., Velvizhi, R. \& Shanmugapriya, K. 2019, "Dual band paper substrate CPW antenna for wireless applications", International Journal of Innovative Technology and Exploring Engineering, vol. 8, no. 9 Special Issue 3, pp. 605-608.

6. Geo, A.V.A., Arunachalam, A.R., Michael, G. \& Elankavi, R. 2019, "Evaluating architecture using compact modalities", International Journal of Innovative Technology and Exploring Engineering, vol. 8, no. 9 Special Issue 3, pp. 836-838

7. Theivasigamani, S., Jeyapriya, D. \& Anita Davamani, K. 2019, "Anamoly analyzing and exploring for wireless sensor networks", International Journal of Innovative Technology and Exploring Engineering, vol. 8, no. 9 Special Issue 3, pp. 1116-1118.

8. Jeyapriya, D., Theivasigamani, S., Velvizhi, R. \& Nandhini, P. 2019, "Program detection in wireless feeler networks", International Journal of Innovative Technology and Exploring Engineering, vol. 8, no. 9 Special Issue 3, pp. 1194-1195.

9. Gowri Sankaran, B., Karthik, B. \& Vijayaragavan, S.P. 2019, "Image compression utilizing wavelet transform", International Journal of Innovative Technology and Exploring Engineering, vol. 8, no. 10, pp. 4305-4308.

10. Gowri Sankaran, B., Karthik, B. \& Vijayaragavan, S.P. 2019, "Weight ward change region plummeting change for square based image huffman coding", International Journal of Innovative Technology and Exploring Engineering, vol. 8, no. 10, pp. 4313-4316.

11. Hema, R., Sundararajan, M. \& Balaji, S. 2019, "Smartphone control robot with automatic firing gun", International Journal of Innovative Technology and Exploring Engineering, vol. 8, no. 9 Special Issue 3, pp. 625-627.

12. Rangaswamy, K. \& Rajabhushanam, C. 2019, "Congestion control in wireless network using TCP friendly rate control (TFRC)", International Journal of Recent Technology and Engineering, vol. 8, no. 2 Special issue 3, pp. 1598-1602.

13. Tamil Selvan, S. \& Sundararajan, M. 2019, "Performance Parameters of 3 Value 8t Cntfet Based Sram Cell Design Using H-Spice", International Journal of Recent Technology and Engineering, vol. 8, no. 2 Special issue 5, pp. 22-27.
14. Vinoth, V.V. \& Kanniga, E. 2019, "Steganographical techniques in hiding text images - system", International Journal of Recent Technology and Engineering, vol. 8, no. 2, pp. 6535-6537.

15. Saravana, S., Balaji, S., Arulselvi, S. \& John Paul Praveen, A. 2019, "Reliable power quality monitoring and protection system", International Journal of Innovative Technology and Exploring Engineering, vol. 8, no. 9 Special Issue 3, pp. 644-645.

16. Sundaramoorthy, A. \& John Wiselin, M.C. 2019, "Single patch antenna with multiple feed", International Journal of Innovative Technology and Exploring Engineering, vol. 8, no. 9, pp. 1743-1747.

17. Velavan, R., Bharanidharan, S. \& Sheeba, B. 2019, "EMF pollution Causes, effects and protection", International Journal of Innovative Technology and Exploring Engineering, vol. 8, no. 9 Special Issue 3, pp. 1166-1168.

18. Veer, R.A., Arulselvi, S. \& Karthik, B. 2019, "Construction of ensemble square classification approaches in MIMO OFDM", International Journal of Engineering and Advanced Technology, vol. 8, no. 5, pp. 2039-2041.

19. Agitha, W. \& Kaliyamurthie, K.P. 2019, "Improved energy efficient in WBAN using MAC with cloud computing", International Journal of Innovative Technology and Exploring Engineering, vol. 8, no. 8, pp. 2405-2408.

20. Kastro, G.G. \& Wiselin, M.C.J. 2019, "Design and analysis of stub loaded resonator", International Journal of Recent Technology and Engineering, vol. 8, no. 1 Special Issue4, pp. 272-283.

\section{AUTHORS PROFILE}

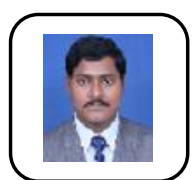

Mohanraj Assistant Professor, Department of Electronics And Communication Engineering,, Bharath Institute of Higher Education and Research, Chennai, India..

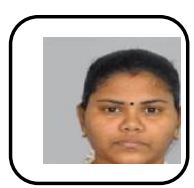

Meenaa Kumari.M, Assistant Professor, Department of Electronics And Communication Engineering,, Bharath Institute of Higher Education and Research, Chennai, India.

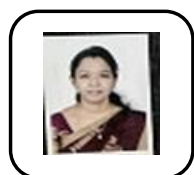

Ramya.S., Assistant Professor, Department of Electronics And Communication Engineering,, Bharath Institute of Higher Education and Research, Chennai, India. 